\title{
Iráčtí jezídé: Případová studie redefinice genderových rolí
}

\author{
KAREL ČERNÝ*
}

\author{
Iraqui Yazidis: Case Study about their Changing Gender Roles
}

\begin{abstract}
The case study of Iraqi Yazidis and their changing gender roles and gender relations as a consequence of armed conflict and forced displacement is based on a field research conducted on the territory of northern Iraq in the Spring 2016. It identifies a complex crisis of Yazidi masculinity as a direct consequence of the armed conflict and forced displacement by the so called Islamic State in the Summer 2014 since Yazidi men have not beet able to fully fulfil their traditional roles and expectations: physically protect their families, women and communities; provide for their livelihood; protect tribal code of honour. Also the tribal and patriarchal authorities are in crisis and alienated from their communities as a direct consequence of the armed conflict, forced displacement and feeling of betrayal on part of the Yazidi population. The forced emancipation of Yazidi women is a direct consequence of the crisis of Yazidi men and an indirect consequence of the armed conflict and forced displacement and as such cannot be understood in isolation from the crisis of the traditional Yazidi manhood. The Yazidi women at least partly fulfil some of the traditional mens' roles like providing livelihood for their families or even participating in the armed struggle against the Islamic State. Redefinition of domestic violence, divorce, and status of women liberated from the sexual slavery is also under way. However, the new dialectics between the crisis of the traditional masculinity and the emancipation of Yazidi women set in motion as a consequence of the armed conflict and forced displacement can become a self-sustaining mechanism even after the forces that have set it in motion disappear.
\end{abstract}

Keywords: Iraq; Yazidis; gender roles; armed conflict; forced displacement; Islamic State

DOI: $10.14712 / 23363525.2019 .4$

\section{Úvod: Zranitelná menšina a útok Islámského státu}

Náboženská synkreze - kombinující islámskou mystiku s předislámskými náboženskými tradicemi - i způsob společenského uspořádání založeného na kastách a endogamii dělá $\mathrm{z}$ jezídů jednu $\mathrm{z}$ nejvíce fascinujících a dlouho málo probádaných a mýty opředených iráckých menšin [Acikyildiz 2010; Domle 2013]. Přitom jde po roce 2003 dost možná o menšinu nejpočetnější, protože iráčtí křestané již ve své většině uprchli ze země [Salloum 2013; Kikoler 2015; Kubálek 2016]. Zároveň jde také o menšinu nejohroženějšíí, která se dle OSN pravděpodobně stala roku 2014 obětí genocidy spáchané Islámským státem [OSN 2016, pro širší kontext viz Jírů 2015; Kudrnáč 2011].

Jezídé se po řadě historických pogromů a opakovaného pronásledování ze strany okolních komunit i státní moci uzavírali a nejevili př́lišné důvěry vưči lidem zvněǰ̌ku [Kubálek

Karel Černý, Pracoviště historická sociologie, Fakulta humanitních studií, Univerzita Karlova, U Křiže 8, 15800 Praha 5. E-mail: karlos.cernoch@post.cz. 
2007]. „Naše historie je plná pronásledování a utrpení. Všichni nás pronásledovali: muslimští Kurdové, guvernéři perských šáhů i osmanští sultáni. Zmasakrovali nás dvaasedmdesátkrát. Mockrát nám unášeli ženy, vyháněli nás z domovů a se vztyčenými šavlemi nás nutili zříci se naší víry. Dej si na tyto lidi pozor, tvrdí o nás, že se modlíme k dáblu. “ Tato slova - v koncentrované podobě odrážející historickou pamět jezídů - pronášel ke své vnučce, dospívající Farídě Chalafové, její děda v předvečer masakrů z roku 2014 [Khalaf 2016: 8]. Nositelka Nobelovy míru Nádija Murádová [2018: 33] si podobně všímá toho, jak se menšinová jezídská identita s novou silou opět formuje právě kolem této kolektivní paměti historických masakrů, tzv. firmanů. Jezídé podle ní věří, že jsou věčnou obětí pronásledování: „Jako děti jsme poslouchali vyprávění o minulých masakrech a vnímali jsme je jako př́běhy, které nás drží pohromadě." Jezídé se na jednu stranu domnívají, že firmany do civilizovaného světa již nepatří. Ale tuší, že současnost není nic jiného než čekání na další masakry, které přijdou. Jen nikdo neví kdy. Genocida z rukou Islámského státu tak tuto vrstvu kolektivní paměti aktualizovala a zpřítomnila specifické čtení historie v podání jezídské menšiny [srov. Omarkhali 2016]. Ti dnes sami sebe chápou jako věčnou obět vystavenou útlaku okolí, který se opět stupňuje od roku 2003 [srov. Maisel 2008].

Útok Islámského státu na vesnice a městečka kolem Sindžáru začal 3. srpna 2014 v časných ranních hodinách. Životy přeživších jezídů jsou od té doby rozervané na dvě části, když uvažují v protichůdných a nespojitelných kategoriích „předtím“ a „potom“. Jak se vyjádřila dospělá jezídka, držená rok a půl v sexuálním otroctví a dvakrát prodaná novým majitelům: „Před útokem Islámského státu jsem byla štastná. Můj manžel mě zbožňoval, miloval naše děti. Vedli jsme dobrý život. Islámský stát mě zadržoval přes rok. Od útoku jsem manžela neviděla. Často o něm sním“ [OSN 2016: 5]. Po dobytí planin Sindžáru islamisté na krátký čas dokonce ohrožovali hlavní město iráckého Kurdistánu Arbíl a dočasně také dobyli jezídské enklávy Bǎšíqa a Bahzání nedaleko Mosulu. Islámskému státu se tak nepodařilo dobýt jen těžko dostupné a nehostinné pohoří Sindžár, kde se s podporou amerického letectva, syrských kurdských Jednotek obrany lidu (YPG) a malé části irácké pešmergy opevnil a zformoval vnitřně nejednotný jezídský odpor [Khanki 2015: 16; Dulz 2016: 142; Knights 2017]. Většina jezídských oblastí oficiálně spadajících pod iráckou provincii Ninive, jakkoliv jsou součástí tzv. sporných území, jež si nárokuje kurdistánská vláda v Arbílu i irácká centrální vláda v Bagdádu, tedy byla v létě 2014 dobyta Islámským státem [Kubálek 2016]. Ze zhruba 90 \% iráckým jezídů se tak stali uprchlíci. 280 tisíc až 345 tisíc jezídů dle odhadi̊ prchlo do kurdské provincie Dohúk [Dulz 2016]. Dalších 70 tisíc odešlo do Evropy, zejména do Německa [Rudaw 2017]. Zatímco však podle televizní stanice Al Jazeera bylo ještě v roce 2015 více než 97 procent jezídských žadatelů o azyl úspěšných, v současné době je úspěšných pouze 83 procent $\mathrm{z}$ nich, množí se žadatelé odmítnutí a deportovaní [Fallon 2018].

Sindžár tak sice od Islámského státu po roce 2014 postupně osvobozovala hlavně kurdská pešmerga a další nezávislé kurdské či jezídské milice, avšak v říjnu 2017 odtud kurdské bojovníky vesměs napojené na Kurdistánskou regionální vládu vytlačila irácká federální armáda, která do oblasti nepouští činovníky kurdské vlády. Vleklý územní spor o sporná území přitom brání nejen dlouhodobému hospodářskému rozvoji Sindžáru, který patří k vládou vůbec nejignorovanější a nejzaostalejší oblasti Iráku, ale i aktuální poválečné rekonstrukci a odminování. Arbíl ani Bagdád do území nechtějí investovat, protože není jasné, komu oblast připadne. Stejně tak půtka o tzv. sporná území brání ve vyšetření 
válečných zločinů, jež se zde odehrály. V Iráku dosud nebyl odsouzen jediný pachatel za zločiny spáchané proti jezídům. Přitom je známo, že se k přespolním a často i zahraničním bojovníkům Islámského státu při útoku na jezídské vesnice přidala i část jejich arabských sousedů. Jezídští uprchlíci se pak kvůli těmto půtkám nechtějí a ani nemohou vracet, sedmdesát procent budov zůstává pobořených, komunikace a infrastruktura včetně dodávek vody nebo elektřiny nefunkční. Podle serveru Middle East Eye se tak do osvobozeného Sindžáru do roku 2018 vrátily jen čtyři tisíce z celkových asi padesáti tisíc rodin, jež odtud v srpnu 2014 prchaly vesměs na sever na území ovládaná Kurdistánskou regionální vládou [Hagedorn 2018].

\section{Výzkumný problém a metodologická východiska}

Cílem předkládané studie je zmapovat, zda a jakým způsobem ozbrojený konflikt provázený následným uprchlictvím vede ke zpochybnění a transformaci tradičních genderových vztahů mezi vysoce konzervativními jezídy z iráckého Sindžáru. Vychází přitom z jednoduchého předpokladu, že sociální role jezídských mužů a žen jsou vzájemně komplementární. Ženské role bez těch mužských nedávají smysl a nelze je proto v izolaci od rolí mužských pochopit a definovat. A také naopak, mužské role nedávají smysl bez těch ženských. Mužské a ženské role se tak na sebe orientují, protože mezi nimi existuje poměrně striktní dělba práce. Proto změny v postavení tradičních jezídských mužů vyvolané ozbrojeným konfliktem a následným uprchlictvím podle našeho předpokladu nutně vyvolají změny v postavení žen. A také naopak, změny v postavení žen následně vedou ke zpochybnění či dokonce redefinici postavení mužů.

Článek proto nejprve představí širší kontext s důrazem na genderové aspekty problematiky iráckých jezídů. Tedy způsob, jakým byla samotná genocida jezídů z rukou Islámského státu provedena, a to s ohledem na systematický vzorec represí, jež různým způsobem dopadaly na různé genderové a věkové skupiny. Dále se vyjádří k tomu, jakým způsobem je genderově zabarven či zkreslen mediální obraz genocidy a zda při jejím mediálním pokrývání nedošlo k výraznému etickému pochybení ze strany novinářuo. Konečně, hlavní část textu bude prezentovat výzkumná zjištění týkající se možného zpochybnění a redefinice tradičního postavení mužů a v návaznosti na to také výzev, které ozbrojený konflikt a uprchlictví přineslo tradičnímu postavení žen, respektive vzájemnému vztahu mužů a žen.

Studie tak vychází z terénního výzkumu a sběru dat provedeného v březnu 2016 na území kurdského severního Iráku (provincie Dohúk) s pomocí více než třiceti polo-strukturovaných hloubkových rozhovorů. Ty zpravidla trvaly půl až jeden a půl hodiny. Rozhovory byly vedeny s jezídskými uprchlíky žijícími v uprchlických táborech i mimo tábory, přičemž byly tlumočeny překladateli rekrutujícími se z jezídské komunity. Kontaktování respondentů a vstup do terénu bylo zajištěno s pomocí tzv. gate keepers, kteří mezi jezídskými uprchlíky požívají důvěru (špičky duchovní hierarchie, jezídští novináři a aktivisté, učitelé či nevládní humanitární organizace). To mělo maximalizovat důvěru respondentů a jejich ochotu na výzkumu participovat. Doplňkově byla realizována řada podrobných rozhovorů s jezídskými akademiky, aktivisty a nejvyššími politickými i náboženskými představiteli. Některé rozhovory byly s ohledem na bezpečnost respondentů částečně anonymizovány. 
Analýza rozhovorů proběhla s pomocí tří druhů kódování. Otevřené kódování, $\mathrm{k}$ němuž docházelo skrze opakované pročítání rozhovorů a terénních poznámek, umožnilo základní tematické rozkrytí pořízených rozhovorů. Seznam kódů v podobě možných dílčích tendencí a změn týkajících se postavení mužů a žen tak poskytl první relativně ucelený a celistvý náhled na data. Přitom stimuloval hledání dalších dílčích motivů, ale i jejich uspořádávání podle vzájemné podobnosti či rozdílnosti. To pak ústilo v postupnou identifikaci abstraktnějších pojmů a obecnějších zastřešujících kategorií seskupujících vzájemně si blízké tendence a změny.

Následně bylo použito tzv. kódování axiální. Jeho cílem bylo nalézt logické či kauzální vztahy mezi kategoriemi odkrytými otevřeným kódováním. Závěrečná fáze analýzy dat pak byla postavena na tzv. kódování selektivním. To si kladlo za cíl vyhledávat nejobecnější kategorie, jež by se staly přímým východiskem pro zformulování teoretického výkladu proměn postavení mužů a žen a především proměny dynamiky jejich vzájemných vztahů [Strauss - Corbinová 1999]. Studie tedy vychází z kvalitativní metodologie pracující s velkým množstvím dat o malém počtu jedinců a usiluje nikoliv o zobecnění vzhledem k jezídské populaci, ale o zobecnění vzhledem $\mathrm{k}$ budované teorii o příčinách pokusů o redefinici genderových vztahů [srov. Hendl 2005].

\section{Genderově zabarvená genocida}

Během útoku Islámského státu bylo s jezídskými zajatci zacházeno systematicky podle unifikovaného klíče: muži a chlapci starší dvanácti let byli obětí nucených konverzí, nebo rychlé smrti, ženy a dívky starší devíti let byly rozprodány na trzích se sexuálními otrokyněmi, mladší chlapce čekalo odloučení od rodin, „převýchova“ a zařazení k bojovníkům Islámského státu.

\section{Muži a chlapci: Konverze, nebo smrt}

Selekce mužů a chlapců starších dvanácti let od ostatních členů rodiny probíhala v jižních regionech Sindžáru na místě, bezprostředně po zajetí bojovníky Islámského státu. Naopak v severních oblastech byly nejprve celé rodiny odváženy do větších shromaždovacích center, kde teprve probíhala selekce. Muži a starší chlapci však bývali v obou případech ihned po selekci popravováni, jelikož vesměs odmítali formálně nabízenou konverzi $\mathrm{k}$ islámu. Kromě toho bývali na místě popravováni také muži chycení při pokusu o útěk. Odlišnosti panovaly jen ve způsobu zabíjení. Jak dosvědčila šestnáctiletá jezídka, která strávila v zajetí islamistů sedm měsíců: „Po zajetí nás Islámský stát nutil přihlížet, jak utíná hlavy některým z našich mužů. Přinutili je pokleknout na kolena v dlouhé řadě na ulici, s rukama svázanýma za zády. Poté bojovníci Islámského státu vzali nože a prořízli jim hrdla" [OSN 2016: 17].

Ve většině př́ípadů se islamisté nesnažili těla mrtvých pohřbívat či jinak skrývat. Naopak je nechávali viditelně ležet na frekventovaných a veřejně přístupných místech, aby tak šírili strach a paniku v řadách ostatních. Tento přístup se týkal nejčastěji prováděného typu poprav, kdy docházelo k velkému počtu exekucí menších skupinek jezídů (2 až 20 mužů). Naopak výjimečné bylo hromadné popravování do masových hrobů, jichž bylo jen během prvního roku genocidy (2014) zdokumentováno přes třicet [Yazda 2016]. 
Exemplárním př́ikladem takového vyvraždování se stala osada Kódžó čítající kolem 1500 obyvatel, kde bylo 15. srpna 2014 postř́leno přes 400 mužů a chlapců [OSN 2016: 8]. Také proto iráčtí jezídé po irácké vládě již několik let požadují bezodkladné otevření šedesáti osmi dosud zdokumentovaných masových hrobů. Prakticky každá rodina má někoho nezvěstného, chce znát pravdu o jeho osudu, aby se se ztrátou blízkého mohla vyrovnat, a také pohnat konkrétní viníky před spravedlnost. Podle serveru Middle East Eye však exhumaci těl a identifikaci totožnosti obětí brání dlouhodobý politický spor irácké centrální vlády v Bagdádu a autonomní Kurdistánské regionální vlády v Arbílu, jehož se stali iráčtí jezídé rukojmími. Obě vlády se tak nejnověji přou o kompetence ohledně exkhumací těl z masových hrobů na tzv. sporných územích, jichž je oblast Sindžáru součástí, přičemž si ji nárokují jak iráčtí Kurdové, tak také většinově arabská centrální vláda v Bagdádu [Hagedorn 2018].

Zvláštní osud pak potkal menšinu jezídů, kteří přijali nucenou konverzi k islámu. Také ti však byli nakonec (jaro 2015) odděleny od svých rodin a zůstávají nezvěstní [OSN 2016: 9]. Patrně nejpodceňovanější a nejzamlčovanější téma genocidy je sexuální násilí páchané na mužích. Zatímco se nejvíce hovoří o sexuálním zotročení jezídských žen, sexuální ponižování mužů je zastřeno dvojnásobným stigmatem a není zdokumentováno. Jeden z mála mužů, kterému se podařilo uniknout ze zajetí, k tomu řekl: „Dělali nám úplně všechno, hlavně v sexuálním slova smyslu“" [Khanki 2015: 23].

\section{Ženy a dívky: Sexuální otroctví}

Také v případě dospělých žen a dívek starších devíti let se islamisté chovali na rozsáhlém území Sindžáru a poté na ještě rozsáhlejším teritoriu Islámského státu v Sýrii a Iráku podle jednotného mustru. Jedinou výjimkou byly starší ženy z vesnice Kódžó, které byly hromadně postř́leny. Po selekci od mužů a starších dětí tak byly ženy a dívky vždy do čtyřiadvaceti hodin deportovány přistavenými autobusy do větších center v týlu Islámského státu. Poté byly v přeplněných centrech (Tel Afar, Mosul, Raqqá) s úřední pečlivostí zaregistrovány, $\mathrm{v}$ některých př́padech také vyfotografovány. Jak dosvědčila dvanáctiletá dívka držená v zajetí sedm měsíců: „Byly jsme zaregistrovány. Islamisté zjištovali naše jména, věk, odkud jsme a zda jsme vdané. A pak si již začali chodit jednotliví bojovníci vybírat dívky, se kterými odcházeli. Nejmladším dívkám bylo devět let. Jedna z nich mi řekla, že když si pro mě přijdou, je lepší vzít si život." Právě od těchto parametrů se odvíjela výsledná cena na trhu s otrokyněmi. Na jejich základě byly dále selektovány a otrokářský trh se segmentoval, aby oslovil jednotlivé kategorie zákazníků (bezdětné svobodné dívky byly zpočátku nejdražší) [OSN 2016: 10; Ajaj 2015].

Trh s otrokyněmi fungoval a expandoval i díky tomu, že docházelo k neustálým nákupům, prodejům, výpůjčkám, výměnám a vzájemnému obdarovávání bojovníků jezídskými ženami. Později se dokonce vyvinula internetová on-line aukce. Mnohé ženy a dívky tak mnohokrát vyměnily majitele, přičemž byly opakovaně znásilňovány. Proto se nakonec ocitly v nejrůznějších koutech Sýrie a Iráku. Jak dosvědčila dospělá jezídka, která v zajetí strávila jeden rok: „V noci jsme byly odvezeny do syrského Raqqá. Tam nás drželi ve velké budově. Než jsem byla prodána, strávila jsem tam asi tři týdny. Během té doby neustále přicházeli nějací muži a nakupovali naše ženy a dívky. Všechny jsme tam byly jezídky. Myslím, že já jsem byla za celou dobu v zajetí prodána asi patnáctkrát. Je opravdu těžké 
pamatovat si všechny muže, kteří si mě koupili.“ Islámský stát takto odprodal zhruba 80 \% jezídských dívek a žen na otrokářských trzích do soukromého vlastnictví. Zbylých asi 20 \% zůstávalo v kolektivním vlastnictví Islámského státu. Tyto jezídky poté v menších skupinkách rotovaly mezi základnami Islámského státu v Iráku a Sýrii, kde byly k dispozici řadovým bojovníkům [OSN 2016: 9-10,12]. Podobně existují svědectví, že během postního měsíce ramadánu Islámský stát organizoval veřejné soutěže v recitování a memorování Koránu, kdy hlavní ceny představovaly zotročené jezídky [Ajaj 2015: 4].

Jezídé samotní zdůrazňují široký repertoár sexuálních zvěrstev. Znásilňování se přitom neděje jen pro potěšení či z ideologických důvodů. Ve hře jsou také racionálně kalkulované strategické motivy. Cílem je totiž zastrašit, ponížit a rozložit jednotlivé oběti i jezídskou komunitu jako celek [Khanki 2015: 22]. Ačkoliv při útocích na jezídské vesnice docházelo $\mathrm{k}$ př́ípadům divokého znásilňování, šlo o excesy. I přes kombinaci množství zadržovaných a bezbranných žen nacházejících se v těsné blízkosti ozbrojených mladých mužů ve skutečnosti nedocházelo $\mathrm{k}$ hromadnému znásilňování. Sexuální násilí tak bylo př́ísně regulováno a docházelo k němu jen předepsaným způsobem [OSN 2016: 12-13].

Muka jezídských žen však pokračovala i po jejich př́padném osvobození. Zejména zpočátku byl pro jezídské komunity velký problém přijmout znásilňované ženy zpět a někdy se s nimi manžel rozvedl. Počáteční ostrakizaci snad prolomila až kampaň náboženských autorit, jež vyhlásily, že ženy zůstávají jezídkami, mají být respektovány a přijaty zpět [tamtéž: 15]. Stigmatizace však trvá a může vést k rozhodnutí dané ženy i celé její rodiny emigrovat do zahraničí. A utéci tak nejen před islamisty, ale i před odsudky od vlastní komunity [UN Habitat 2015: 14; Khalaf 2016]. Otevřeněji diskutovaným problémem jsou pak psychická traumata, se kterými se zneužívané ženy v depresivním prostředí uprchlických táborů a bez adekvátní psychiatrické péče a terapie jen těžko vyrovnávají [OSN 2016: 16]. Post-traumatický stresový syndrom se některým jezídkám daří překonat díky odborné pomoci poskytnuté unikátním humanitárním projektem iniciovaným německou spolkovou zemí Bádensko-Württembersko. Ten od roku 2015 do Německa převezl a poskytl zde pomoc více než 1100 jezídským ženám a jejich dětem, kterým se podařilo dostat ze zajetí. Odborným garantem tohoto projektu se stal kurdský psycholog Jan Kizilhan z univerzity v kurdském Dohúku. Ten na serveru televizní stanice Al Jazeera připomněl, že na území celé Kurdistánské regionální vlády působí pouze dvacet šest vyškolených psychoterapeutů. To je na pět a půl miliónu místních obyvatel a dalších možná až jeden a půl miliónu traumatizovaných válečných uprchlíků naprosto nedostačující. Irácká populace čelící válečným traumatům je proto závislá na pomoci zahraničních odborníků, jejichž efektivita je však nižší, protože se neorientují v kulturních reáliích regionu. Momentálně proto vzniká projekt, v jehož rámci by měly kurdské univerzity vychovávat několik desítek psychologů a psychoterapeutů ročně [Ekin 2018; Castelier - Daycard 2018].

\section{Děti: Převýchova}

Jezídské děti - dcery mladší devíti let a synové mladší sedmi let - bývaly na trzích s otroky prodávány spolu s matkami. Jakmile však dcery dosáhly vyššího věku, bývaly odděleny a prodávány novým majitelům. Chlapci pak byli od matek oddělováni po dosažení sedmi let věku a posíláni do výcvikových táborů na převýchovu a poté jako dětští vojáci nebo sebevražedný atentátníci do bojů. Jak vypovídá dvanáctiletý chlapec cvičený 
islamisty v Sýrii: „Řekli nám, že se musíme stát dobrými muslimy a bojovat za islám. Ukazovali nám videa s popravami, zabíjením a válčením. Můj instruktor mi říkal, že musím zabíjet nevěrící (kuffár), i kdyby to měl být můj otec nebo bratři. Protože prý patří ke špatnému náboženství a nemodlí se k Bohu“ [OSN 2016: 18-19]. Přitom se uvádí, že zejména stávající situace chlapců vystavených násilí i bojům na frontě je velmi komplikovaná a podceňovaná. Jestliže se nedostává odborníků schopných pracovat $\mathrm{s}$ traumatizovanými dospělými, dostupní dětští terapeuti absentují zcela [tamtéž].

\section{Gender a mediální pokrytí genocidy: Přehled stávající literatury}

Jezídské oběti genocidy se tedy ve své zkušenosti s ní liší, a to na základě věkové a především genderové skupiny, ke které náleží. Proto mezi nimi koluje větší množství narací, které odráží širokou škálu jejich zkušeností. Tyto narace vyprávějí z různých perspektiv př́iběh prožitého utrpení a zároveň ho také zasazují do širšího historického a politického kontextu. Tímto způsobem se jezídé pokoušejí pochopit, co se jim vlastně stalo, př́ípadně to sdělit ostatním.

Avšak západní média si podle Veronicy Buffon a Christine Allison [2016] odpočátku vybrala jen jednu naraci, jež dominuje západnímu mediálnímu diskurzu týkajícímu se katastrofy iráckých jezídů: př́iběh zhruba sedmi tisíc jezídských dívek a žen zajatých a následně sexuálně zotročených bojovníky Islámského státu. Západní fascinace tímto př́iběhem poté vytlačuje a umlčuje ostatní narativy, což však západnímu publiku brání pochopit šiři dopadů genocidy i její klíčové souvislosti. Mediální super-viditelnost (hyper-visibility) ženských obětí je totiž doprovázena neviditelností obětí mužských, jedná se tak o dvě strany téže mince.

Mediálně nejznáměǰ̌́m př́během blízkým naraci zdůrazňující sexuální zotročování jezídských žen je ten Nádiji Murádové, jakkoliv se tato aktivistka oceněná Nobelovou cenou míru (2018) z této jednorozměrné role snaží zas a znovu vystoupit. Nádija Murádová si zřejmě dobře uvědomuje logiku fungování západních médií. Rozumí tomu, že západní média lační po př́ibězích týkajících se sexuálního zotročování žen. Hraje tuto hru, aby se do západních médií, světových institucí a veřejného povědomí vůbec dostala. Poté se ale pokouší z tohoto jednorozměrného narativu vystoupit a podat vícerozměrné a komplexní svědectví o jezídské negativní zkušenosti s genocidou, uprchlictvím, iráckou i kurdskou vládou.

Murádová se však předně odmítá stát pasivní a submisivní obětí. Vyrovnat se s posttraumatickým stresovým syndromem jí zřejmě daleko více než v Německu nabídnutá terapie pomohlo, že jako aktivistka bojující za práva a důstojnost znásilňovaných žen získala nový smysl života. Jak se sama vyjádřila v souvislosti s udělením Nobelovy ceny pro deník Guardian: „Vyprávím svůj př́běh, protože to je ta nejlepší zbraň, kterou mám.“"V listopadu 2015 tak z Německa odjela do Švýcarska, aby poprvé promluvila před velkým publikem na fóru o menšinách pořádaném OSN. Jak sama vzpomíná, chtěl tehdy hovořit úplně o všem, ale uvědomovala si, že o všem již jen z časových důvodů mluvit nelze. Tedy o dětech, které na útěku před Islámským státem $\mathrm{v}$ parném létě umíraly na dehydrataci. O obklíčených rodinách chycených $\mathrm{v}$ pasti na rozpálených úbočích pohoří Sindžár. O ženách a dětech zůstávajících $\mathrm{v}$ zajetí. Nebo o tom, co její jediný přeživší bratr viděl na místě, kde došlo $\mathrm{k}$ masakru jezídských mužů $\mathrm{z}$ jejich vesnice. Již tehdy přitom ve jménu iráckých jezídů 
vznášela jasné a konkrétní požadavky. Chtěla, aby v Iráku vznikly bezpečné a vojensky chráněné zóny pro náboženské menšiny. Chtěla, aby byli souzeni bojovníci Islámského státu, od velitelů až po jejich přisluhovače z řad běžných občanů, za zločiny proti lidskosti a za genocidu spáchanou na jezídech. A samozřejmě již tehdy požadovala, aby došlo k co nejrychlejšímu osvobození Sindžáru a návratu jezídů zpět do jejich domovů. Aby byl její př́iběh uvěřitelný a měl patřičnou váhu, uvědomila si, že bude muset promluvit i o tom, jak jí opakovaně znásilňoval a trýznil její vlastník, Hadži Salmán.

Toto rozhodnutí o naprosté otevřenosti prý bylo jedním z nejtěžších v jejím životě, ale také tím nejdůležitějším. Dokázalo přitáhnout pozornost novinářů a světového společenství. V prosinci 2015 tak Murádová promluvila před Radou bezpečnosti OSN o obchodu s lidmi ve válečných zónách. $V$ roce 2016 s ní začala spolupracovat světově uznávaná právnička Amal Clooney a připravovat žalobu na činovníky Islámského státu týkající se obchodování s lidmi, znásilňování žen a genocidy na jezídech. Následovalo jmenování Velvyslankyní dobré vůle OSN, udělení řady mezinárodních cen, vystupování v médiích, setkání s papežem a publikování knihy Poslední dívka (anglicky 2017), jejíž název má evokovat autorčino přání, aby byla historicky poslední dívkou znásilněnou v ozbrojeném konfliktu. A nakonec přišla i Nobelova cena míru (2018) [srov. Murádová 2018].

\section{Možné př́ičiny genderové deformace mediálního obrazu}

Proč př́iběhy vyprávěné perspektivou jezídských mužů, dětí nebo žen neodvlečených do sexuálního otroctví ustupují do pozadí? A proč dochází k tak výrazné selekci, kdy se z mnoha autentických jezídských narativů vybírá pouze ten o sexuálních otrokyních?

Za prvé se jedná o důsledek načasování, kdy se tento narativ objevil jako první a měl tak šanci se etablovat a vytěsnit ty ostatní. Záhy po útoku Islámského státu totiž vystoupila $\mathrm{v}$ iráckém parlamentu $\mathrm{s}$ mimořádně emotivním projevem doprovázeným prosbou o pomoc jezídská poslankyně Viján Dakhil. Ve stejný den pak bagdádské ministerstvo pro lidská práva zveřejnilo zprávu o pronásledování jezídů. Oba mediální výstupy přitom zdůrazňovaly utrpení a sexuální zotročování jezídských žen právě v momentě, kdy se západní veřejnost a média začala poprvé zajímat o to, kdo jsou jezídé a čemu v Iráku čelí. Téma sexuálního zotročení jezídských žen se tak stalo základem pozdějšího západního mediálního narativu díky tomuto načasování. Narativ se poté etabloval během léta 2014, když nevládní organizace neúspěšně lobovaly za osvobození zajatých žen speciálními jednotkami dříve, než budou z centrálních tržišt (Tel Afar, Mosul) rozprodány a rozptýlí se tak na rozsáhlých teritoriích Islámského státu v Iráku a Sýrii. Aktivisté také nabádali první osvobozené jezídky, aby o svém utrpení ochotně hovořily se západními novináři, přičemž šokující př́iběh o zotročování jezídských žen popularizoval i samotný Islámský stát, když o něm otevřeně informoval.

Za druhé, dominantní narace jezídské genocidy se uchytila také proto, že zapadá do již existujících západních klišé a stereotypů. Orientalistický diskurz je totiž dlouhodobě fascinován útlakem nezápadních žen ze strany údajně barbarských, násilnických a nekontrolovatelnou sexualitou posedlých muslimských mužů. Proto západní novináŕi a jejich západní publikum s oblibou odkrývali i ty nejmenší detaily z prodělaného utrpení v zajetí a z následného útěku těchto žen na svobodu. Naopak odhlíželi od zdánlivě méně dramatického kontextu uprchlictví nebo od toho, že to byli nakonec mnohdy právě muslimové, kdo 
jezídkám pomáhal na svobodu. Narativ jezídských sexuálních otrokyň je v této perspektivě jen posledním vydáním dlouhého seriálu příběhů ze strany muslimů zneužívaných žen, jež známe z tzv. harémové literatury. Jediný, kdo snad může v této orientalistické perspektivě zachránit blízkovýchodní ženy od útlaku blízkovýchodních mužů, je kladný hrdina v podání bílého křestanského muže. Dominantní narace o sexuálně zotročených jezídkách proto také může sloužit k ospravedlnění humanitární či vojenské intervence ve prospěch jezídské komunity jako celku.

Za třetí, tato narace byla samotnými jezídy rozpoznána jako efektivní nástroj politiky oběti. Jezídská komunita záhy pochopila, že jakožto bezbranná a málo vlivná menšina může získat v mezinárodním kontextu vliv a respekt, pokud zformuluje silný př́běh a bude $s$ jeho pomocí hovořit z pozice oběti. Stejně tak i jednotlivé zneuctěné a zlomené jezídské ženy pochopily, že se díky svému svědectví mohou postavit znovu na nohy a dát svému životu nový smysl, když se stanou vlivným a žádaným hlasem symbolizujícím směrem navenek utrpení celé komunity. Svědectví obětí sexuálního násilí tak slouží jako morální apel na jednotlivé země i mezinárodní společenství, aby na jezídy nezapomínalo a poskytlo jim humanitární i vojenskou pomoc. Jezídé vlastně zopakovali tutéž strategii, kterou od 90. let 20. století používají jejich bezprostřední sousedé, tedy iráčtí Kurdové. Ti vystupují v roli oběti, když se snaží skrze mezinárodní uznání genocidy z 80. let 20. století (tzv. kampaň al-Anfál z éry diktatury Saddáma Husajna) o uznání svých nároků na nezávislost a v krátkodobém horizontu o př́liv financí na poválečnou rekonstrukci zničených oblastí. Podobně není náhodou, že s osudem jezídů sympatizují četné židovské organizace, nabízejí pomoc a spolupráci. Přitom také legitimita státu Izrael se podle některých autorů mimo jiné opírala o politiku oběti: aby bylo možno zabránit dalším pogromům a holocaustu, židé musí dostat svůj vlastní stát, kde je již napříště nebude nikdo diskriminovat [podle Buffo Allison 2016].

\section{Dilemata politiky oběti}

Politika oběti však otevírá četná dilemata. Stejně jako iráčtí Kurdové také jezídé musejí vyřešit konfliktní otázku, kdo je oprávněn hovořit jménem obětí a co bude jejich jménem požadovat. Na jednu stranu proto vidíme představitele hájící jménem obětí agendu Kurdské demokratické strany. Na druhou stranu vidíme nadstranické aktivisty, jako je Nadia Murad, která nedůvěřuje irácké centrální vládě v Bagdádu ani Kurdské regionální vládě v Arbílu a od mezinárodního uznání genocidy si slibuje budoucí mezinárodní ochranu jezídské menšiny garantovanou OSN či velmocemi. Druhým dilematem je, že západní média očekávají př́běhy týkající se sexuálního zotročování žen. Jezídští reprezentanti na jednu stranu musejí tuto hru hrát, aby se do západních médií vůbec dostali. Na druhou stranu se pak ale mnohdy pokoušejí vystoupit z jednorozměrného narativu a podat vícerozměrný obrázek jezídské zkušenosti.

Třetí dilema pak souvisí s negativními dopady tohoto narativu na jezídské muže. Narativ může sloužit jako efektivní instrument politiky oběti, avšak také přispívá $\mathrm{k}$ dalšímu ponížení a utrpení jezídských mužů. Nejde zdaleka jen o to, že západní média nedávají jezídským mužům hlas, a pokud jim ho dávají, očekávají, že budou hovořit o utrpení svých žen. Jezídští muži totiž byli tradičně líčeni jako hrdinové, léto 2014 však nemá hrdinů, dominuje př́iběh obětí. Jezídští muži tedy nedokázali splnit tradiční závazky, tedy 
ochránit své rodiny. Stud je o to větší, že jezídy uvízlé v létě 2014 na hoře Sindžár zachránila intervence syrských Kurdů, v jejichž řadách bojovalo mnoho žen. Ani jako uprchlíci nejsou muži schopní pomoci svým uneseným a zotročeným ženám a dcerám, musí se opět spoléhat na intervenci cizích vojáků. Díky dominantnímu mediálnímu narativu je celý svět svědkem jejich selhání, jsou tak vystaveni celosvětové ostudě. Navíc celý svět doslova zírá na jejich znásilňované ženy a je fascinován představou jejich zraňovaných těl, přitom jezídští muži jsou tradičně nejraději, pokud se pohledy cizích mužů jejich ženám vyhýbají [Buffo - Allison 2016].

\section{Novinářská etika: Selhání médií při získávání svědectví v terénu}

Nádija Murádová sdílí osud s mnoha dalšími jezídskými ženami. Stejně jako mnoho dalších se i ona rozhodla promluvit o utrpení svém a své komunity. Její hlas je však hlasem privilegovaným. Možnost podávat svědectví jí dodalo sebevědomí, důstojnost a nový smysl života. Zkušenost mnohých jezídských žen s médii je však odlišná. Terénní výzkum jezídských žen přišel na flagrantní porušování novinářské etiky ze strany západních i místních médií, která zpovídala jezídské oběti sexuálního násilí ze strany Islámského státu. Média předně nerespektovala přání zpovídaných žen nezveřejňovat jejich plnou identitu, případně fotografie či televizní záběry. Osvobozené ženy a dívky se přitom obávají reálnosti výhrůžek militantů, že je najdou, unesou a budou opět znásilňovat. Vědí také, že kritická svědectví pronesená osvobozenými jezídkami na adresu bojovníků Islámského státu vedou ke zvýšenému násilí a pomstychtivosti vůči těm $\mathrm{z}$ nich, které se ještě nacházejí v zajetí a jsou v př́buzenském poměru s těmi, jež se odhodlaly promluvit do médií. Vícero respondentek výzkumu tak například uvedlo, že když v televizi mluvila právě Nádija Murádová nebo se referovalo o jejích aktivitách v OSN, islamisté vždy ve zvýšené míře trýznili jezídky Z vesnice Kódžó, odkud pochází také samotná Murádová. Kapitolou samou o sobě je pak podle výzkumu skutečnost, že znásilněné jezídky byly sice oficiálně přijaty zpět do svých rodin a komunit, nicméně se znásilněním spojené stigma, pocit studu a ponížení je natolik velké, že jezídské ženy nestojí o jmenovitou publicitu [Foster - Minwalla 2018].

Druhým problémem je, že jezídské ženy byly k rozhovorům s novináři zpravidla nuceny. Vůdci jezídských komunit nebo ředitelé táborů stály o to, aby se svět o jejich zoufalé humanitární situaci dozvěděl. Očekávali proto, že ruku v ruce s publicitou přijde také pomoc a ochrana. Na jezídské ženy proto poté tlačili také jejich mužští př́ibuzní, kteří mají v silně patriarchální společnosti hlavní slovo. Jezídské ženské oběti tak nejsou a nikdy nebyly svobodnými individualitami, které by si samotné mohly rozhodnout, zda interview poskytnou [tamtéž: 56].

$\mathrm{K}$ tomu všemu se pak přidalo vysoce necitlivé vedení rozhovorů. Třetím problémem tak bylo, že novináři často požadovali nejdetailnější podrobnosti o tom, jak docházelo ke znásilňování, jak se při tom oběti cítili. Šlo přitom o věci, o kterých se jezídské ženy nebavily ani se svými nejbližšími. Vyprávění příběhu pro ně znamenalo to, že si musely opět projít fyzickým i mentálním utrpením, které zažívaly z rukou militantů. Novináři sami i jejich tlumočníci navíc bývali zpravidla muži, což ještě zvyšovalo diskomfort jezídských obětí sexuálního násilí, jak se vyjádřila jedna z nich: „V̌̌dy se nás ptali na věci, které nás zraňovali a uváděli do hlubokého smutku. "Všechny respondentky výzkumu se pak v této souvislosti shodovaly na tom, že psychický stav žen po dokončení rozhovorů býval 
výrazně horší než před jeho započetím, některé zůstávaly dlouhé hodiny paralyzovaně ležet a musely jim být podány utěšující léky: „Hrozně se rozplakaly. Moje nejmladší dcera udělala rozhovor krátce poté, co byla osvobozená. Rozplakala se a byla natolik zoufalá, že si prý myslela, že musí každou chvílí zemřít“ [tamtéž: 57-58].

Na druhou stranu osvobozené oběti sexuálního násilí, které ztratili domov, majetek, často i všechny své blízké a neměli vůbec nic, si tváří v tvář novinářům uvědomili, že ve skutečnosti mají vysokou cenu, pokud budou ochotné zas a znovu vyprávět svůj děsivý př́iběh, o který mají domácí i mezinárodní média takový zájem. To jim dodalo sebevědomí. Vyprávění př́běhu tak pochopili jako svou obět ve jménu jezídské komunity, přátel a př́buzných. Doufali, že pokud zvýší povědomí o utrpení jezídů, svět na něj nezapomene a přijde včasná a efektivní pomoc. V tomto je ostatně utvrzovali i samotní novináři, ve vzbuzování neoprávněných očekávání a v nedostatečném objasnění omezené role novinářů tak spočívá čtvrté novinářské selhání. Smysluplnost dávání rozhovorů pro média tak pokládaly za mimořádně důležité především jezídky, jež si prošly sexuálním zotročením, nikoliv jezídky, jež sexuálním zotročením neprošly, ačkoliv právě pro ně byla interview dvojnásob obtížná a zraňující. O to větší zklamání a frustrace se pak dostavilo, když jezídky viděly, že i přes veškerou publicitu a přes rozdané slzy a rozhovory jezídům žádná efektivní pomoc nikdy nepřišla. Podle nich obrovský mediální zájem o jezídskou genocidu kontrastuje s absencí jakékoliv mezinárodní i domácí pomoci. Jak se vyjádřila jedna z žen: „Nikdo nám nepomohl. Cítili jsme se smutné a vyčerpané, a oni si udělali svou práci, vše si zapsali a prostě odjeli. My jsme očekávali, že nám pomohou, byt' i s nějakou drobností. Ale oni se tu již nikdy neobjevili a nic pro nás neudělali“ [tamtéž: 59].

Poskytování interview tak některé jezídky pojaly jako paradoxní akt odporu skrze sebeviktimizaci. Zdaleka ne všechny se tak cítily jen jako pasivní oběti mediálního zájmu, část naopak pocitovala dosud neznámý pocit zplnomocnění (empowerment) a interview s novináři chápala jako vyjednávání o tom, co jim řeknou a co tím ony samy nebo celá komunita získají. Přitom se ale ukázalo, že se jedná o akt značně nerovnoměrné směny, kde obě strany něco dávají a od té druhé něco očekávají. Zatímco se však jezídky před médii bolestně obnažují a odkrývají svůj příběh sexuálních otrokyň, novináři jim za to prakticky nic nenabízejí, vyjma vágního příslibu, že podané svědectví zranitelné komunitě pomůže [Foster - Minwalla 2018].

\section{Statusová krize jezídských mužů: Neschopnost dostát tradičním závazkům}

Jezídští muži čelí v důsledku ozbrojeného konfliktu, genocidy a souvisejícího nuceného vysídlení zpochybnění svého společenského postavení. Z pozice příslušníků zranitelné menšiny a uprchlíků nadále nedokáží plnit své tradiční funkce, role a závazky, které vždy měli vưči svým komunitám, rodinám a ženám. Koncept mužství přitom vychází z kmenových a patriarchálních hodnot. Ty jsou silné zejména mezi jezídy z chudého, periferního a dlouhodobě konzervativního Sindžáru, který útokem Islámského státu utrpěl nejvíce. Přitom můžeme hovořit o třech typech tradičních povinností, které muži v důsledku ozbrojeného konfliktu a uprchlictví nedokáží nadále plnit: zajistit fyzické bezpečí svým rodinám a komunitám; rodinám a komunitám zajistit materiální zdroje nutné pro přežití; ochránit pověst a čest svého kmene a rodin, jež se často odvíjí od „čistoty“ jejich ženských 
příslušníků. Ve výsledku se jezídští muži cítí dezorientovaní a frustrovaní, jejich společenský status a mužská čest je narušena a zpochybněna.

\section{Neschopnost ochránit ženy, rodiny a komunity}

Jedna z mála kariérních možností se v novém Iráku po roce 2003 pro př́íslušníky méně vzdělaných menšin jako jsou jezídé otevírala u bezpečnostních složek [After ISIS 2015]. Jelikož v provincii Ninive sloužilo mnoho jezídských mužů na nižších pozicích v irácké armádě nebo u pohraniční stráže (hranice se Sýrií), cítili se někteří z nich spoluodpovědní za ochranu jezídských komunit. Jezídští muži proto nesou dvojnásob těžce selhání dobře vycvičené a dobře vyzbrojené irácké armády, která se během léta 2014 pod náporem Islámského státu rozpadla. Zdůrazňují ochotu řadových vojáků bojovat a bránit se, přičemž vinu za kolaps armády kladou na důstojníky a politiky. Podle šestadvacetiletého jezídského uprchlíka Dáwúda Hasana, jenž sloužil sedm let v irácké armádě, se důstojníci do velitelských pozic dostávali s pomocí korupce a konexí. Nikoliv na základě schopností a zkušeností, takže nebyli kompetentní svým jednotkám v boji velet a mužstvo jim nedůvěřovalo. Nebo se jednalo o sice zkušené šíitské důstojníky dosazené do pozic sektářskou bagdádskou vládou tehdejšího premiéra Núrí al-Málikí, která z armády vylučovala údajně neloajální sunnity. A tito velitelé zase nehodlali umírat při obraně „cizích“ kurdských či sunnitských oblastí, které nepokládali za svou šiitskou vlast. Zhroucení irácké armády tak během léta 2014 vzalo řadě jezídských mužů možnost účinně bránit v jejích řadách jezídské komunity.

Druhým důvodem, proč jezídští muži selhali při ochraně svých komunit, je zrada Kurdské regionální vlády. Ta jezídům opakovaně slibovala, že jejich území před Islámským státem namísto dezintegrované irácké armády ochrání kurdská pešmerga. Kurdští muži pak mylně ujištovali své rodiny, že se nemusejí bát. Avšak 3. srpna 2014 se pešmerga bez varování z úseku fronty chránícího jezídské vesnice v Sindžáru stáhla. Jakkoliv se patrně jedná o klíčový zdroj frustrací jezídských mužůu, uprchlíci se ke Kurdské regionální vládě nechtějí ze strachu vyjadřovat. Jak mi řekl šedesátník Qaró v táboře Chánke: „Kurdská vláda nás měla ochránit, když to slíbila. Je proto přímo zodpovědná za naši současnou zoufalou situaci. Hrozně nás to tady všechny rozčiluje, ale raději se o tom nechci bavit."

Třetím důvodem, proč muži selhávají ve své tradiční funkci obstarat svým rodinám a komunitám fyzické bezpečí je skutečnost, že se jim nedařilo osvobodit zajaté jezídské ženy ze sexuálního otroctví. To je pro mužské příbuzné, ale i pro jezídské muže jako celek, mimořádně ponižující a frustrující. Vše je z pohledu jezídských mužů dále zhoršeno tím, že se musejí spolehnout na to, že jejich ženy osvobodí cizí bojovníci z irácké armády, kurdské pešmergy nebo západních speciálních jednotek. Často je zdůrazňováno, že o mužství jezídští muži přicházejí kvưli pocitu zoufalství a bezmoci plynoucího ze sexuálního zneuctění svých žen. Mladý zpěvák v uprchlickém táboře Zacho to vyjádřil takto: „Nebudu zpívat jezídské písně, dokud se nevrátí naše matky a sestry (...) at třeba muži zůstanou pohřešovaní, ale ženy a dívky at’ se nám vrátí (...) ženy jsou slabé, potřebují podporu (...) lidé nikdy nepochopí, co to je, když ti telefonuje sestra nebo dcera a prosí, at ji přijdeš zachránit“ [podle Buffo - Allison 2016: 187]. Nejtěžšími depresemi zřejmě trpí právě mužští příbuzní obětí sexuálního násilí. Jak mi řekla kurdská psycholožka Džamíla Júnis Sulajmán 
z tábora Qádijá: „Nedávno jsme v táboře měli sebevraždu. Zabil se dvaadvacetiletý bratr jedné z unesených dívek. Již to nemohl vydržet. Bohužel to je dost časté.“

Jezídští muži se mohou snažit získat zpět svou ztracenou mužskou čest tím, že napříště dokáží svým rodinám a komunitám zajistit bezpečí, případně se pomstí za prodělaná příkoří. Proto jezídští uprchlíci často volají po zbraních, po vlastních milicích a po pomstě [srov. After ISIS 2015]. Jak se nechal slyšet hned 12. srpna 2014 jeden jezídský uprchlík: „Dejte mi zbraň a půjdu bojovat. Dejte zbraně všem jezídským mužům. Dejte nám šanci bojovat za naše rodiny nebo v tomto boji zemřít. To je vše, o co žádám“ [podle Buffo Allison 2016: 187]. Mnoho jezídských uprchlíků proto vstoupilo do řad kurdské pešmergy. Avšak i zde mají problém vyreklamovat své mužství, když si stěžují na diskriminaci v jejích řadách. Například čtyřicátník Chéró se k pešmerze přidal hned, co se stal uprchlík: „Je to ale naprosto frustrující. Od založení jezídské jednotky jsme na rozdíl od ostatních nedostali žádný žold. Musíme dokonce rozprodávat části výstroje, abychom získali munici. A přesto, že jsme statečnější než ostatní, máme nejhorší zbraně. Úplně předpotopní. Takže až bude ofenzíva, tak na islamisty snad radši půjdeme s klacky a kameny. Je to nefér.“

Vedle touhy jezídských mužů podílet se na osvobozování svých vesnic od Islámského státu může být pomsta druhým způsobem, jak si znovu získat ztracenou mužskou čest. Jak mi řekl třicátník Salím živící se jako učitel v uprchlickém táboře Chánke: „Pět arabských vesnic $\mathrm{v}$ našem okolí se hned přidalo $\mathrm{k}$ Islámskému státu. Vyhnali nás a zničili náš majetek. Bylo prolito mnoho krve, smíření si nedovedu představit. Jakmile získáme zbraně, tak se jim tvrdě pomstíme a vyženeme je. A bezpečí domovů si pak zajistíme ve své režii.“ Podobně bojovně hovoří i bývalý voják federální armády, šestadvacetiletý Dáwúd Hasan: „Jezídé by se měli z Evropy vrátit. Měli by být tady a bránit vlastní zemi. Odchod do emigrace je známka, že jsme boj prohráli. A doklad toho, že naši nepřátelé vyhráli. To nikdy nepřipustím.“

Série skupinových rozhovorů (tzv. focus groups) s uprchlíky z různých etnických a náboženských skupin žijících v provincii Ninive ukázala, že všichni uznávají, že právě jezídové v důsledku útoku Islámského státu utrpěli nejvíce. Jak prohlásil jeden z respondentů: „Ve srovnání s jezídy se nám vlastně nic nestalo.“ Jezídé se proto ukázali jako nejvíce traumatizovaní, nejméně důvěřuící svým arabským sousedům, jež viní z kolaborace s islamisty, a nejvíce pomstychtiví, když pomstu nejčastěji pokládají za podmínku návratu do svých domovi̊. Ostatní uprchlické skupiny přitom tyto jezídské postoje chápou jako „pochopitelné“ či „legitimni““ [After ISIS 2015: 55, 65, 67].

\section{Neschopnost materiálně zajistit rodiny}

Zatímco ženy-uprchlice deklarují stesk po domově (emoční vazbu) a stěžují si na náročnost obstarat v podmínkách uprchlictví chod domácnosti, muži si nejvíce stěžují na ponižující závislost na pomoci a na neschopnost najít si v iráckém Kurdistánu práci, se kterou by byli schopni důstojně uživit rodinu [tamtéž: 70]. Přitom jezídé z konzervativní oblasti Sindžáru respektují jasnou dělbu mužských a ženských rolí. Ženy tráví čas v domácí sféře, starají se o vesměs početné potomky, o chod domácnosti a př́ípadně o hospodářství. Muži bývají výhradními živiteli rodiny, pohybují se ve veřejné sféře a nejčastěji pracují v zemědělství, v ozbrojených složkách nebo jako drobní obchodníci či nekvalifikovaní dělníci. S jasně vymezenou tradiční dělbou genderových rolí a zodpovědností však nucené 
vysídlení otřáslo. Muži totiž již nedokáží uživit své rodiny, a jejich tradiční status je tak zpochybněn.

Prvním důvodem je to, že v důsledku nuceného přesídlení ztratili přístup $k$ půdě $a$ živnostem. Jejich farmy a dílny byly navíc po útoku Islámského státu cílem ničení a rabování ze strany sunnitských Arabů žijících v sousedních vesnicích. Proto si jezídé uvědomují, že budou mít problém uživit své rodiny i v př́padě, že se jejich vesnice od Islámského státu podaří osvobodit a oni budou mít možnost vrátit se zpět do svých domovů. Jak mi řekl šedesátiletý pologramotný pastevec Qaró, otec deseti dětí: „Mým snem je vrátit se do vesnice, cítit se tam bezpečně, pracovat a žít jako předtím. Jenže není nic těžšího než po tom všem začít znovu. Nic nebude jako dřív. Ale Bůh je velký. On nám snad pomůže. "Přitom je zapotřebí zdůraznit, že uprchlíci z konzervativních oblastí Sindžáru touží pracovat nejen kvưli př́ijmu, který potřebují k přežití. Ale také proto, že byli celý život uvyklí tvrdě pracovat a nyní se cítí ponížení a neužiteční právě pro vynucenou zahálku. Kromě toho hovoří o tom, že úlevu od traumat způsobených útokem Islámského státu a také únosem svých žen, pocitují jen při práci. Jedině při práci prý na čas zapomínají na svá trápení, získávají ztracenou důstojnost, pocit užitečnosti a vnitřní klid.

Druhým důvodem, proč muži ztrácejí schopnost uživit své rodiny je, že se jezídé během chronické uprchlické krize propadají do chudoby a dluhové pasti. Např́ílad po dvou letech od vypuknutí genocidy byla poptávka po místech v uprchlických táborech vyšší než jejich nabídka. A dokonce se tento nepoměr podle některých hlasů zvětšoval. Jak mi řekl například Daján Dža'far, ředitel tábora Chánke, stále se zvětšuje existující pořadník čítající stovky až tisíce zájemců, které musí odmítat. Větší část uprchlíků se totiž zprvu ubytovala mimo tábory: u př́buzných, ve veřejných budovách, v rozestavěných domech nebo v pronajatých bytech. Nyní však vyčerpali své úspory, rozprodali majetky, jež zachránili (často se jedná o ženské šperky sloužící jako svérázná forma pojištění), a nyní nemají na nájem ani potraviny. Proto žádají o místa v táborech. Např́klad paní Piroz Othoman (45 let) pocházející z vesnice Du Gure na sever od Sindžáru trpí cukrovkou. Prodělala již několik operací na soukromé klinice mimo uprchlický tábor. Léčba nejprve vyčerpala rodinné úspory a manžel poté prodal i automobil, se kterým rodinu před Islámským státem zachránil a poté ji jako řidič a obchodník živil při pobytu v táboře.

Třetím důvodem, proč dochází k otřesení tradičního statusu jezídských mužů-uprchlíků, jsou nevyhovující materiální podmínky v táborech a ponižující závislost na humanitární pomoci. Jestliže ženské uprchlice $\mathrm{z}$ řad jezídů i dalších menšin nejhůře nesou těžký život v táborech, kdy je daleko složitější řídit chod domácnosti a výchovu dětí, a také stesk po domově, mužští uprchlíci zdůrazňují ponižující závislosti na pomoci a obtíže s hledáním pracovních příležitostí na území iráckého Kurdistánu [srov. After ISIS 2015]. Muži se tedy cítí zodpovědní za zajištění ženami očekávaného životního standardu svých rodin a zároveň těžce nesou, když svým rodinám v situaci uprchlictví požadovaný materiální standard nejsou schopni zajistit. Nejčastěji si uprchlíci v materiální oblasti podle mého výzkumu stěžují na nedostatek toalet a teplé vody, výpadky elektřiny, nevyhovující stany nebo nepravidelnost a nespolehlivost potravinové pomoci.

Řada uprchlíků si tak stěžuje, že zatímco se humanitární situace v iráckém Kurdistánu zhoršuje, humanitární organizace odcházejí. Např́klad Khalil Nassir Murad pracuje od začátku uprchlické krize v roce 2014 jako tzv. muchtár. Ve městě Zacho je tak zodpovědný za distribuci pomoci pro tisícovku krajanů žijících mimo uprchlické tábory, kteří spolu 
s ním utekli ze Sindžáru. Jak ale říká, pomoci je stále méně a někteří běženci nemají zajištěny ani nejzákladnější životní potřeby jako je pravidelný a spolehlivý př́istup k pitné vodě a jídlu. Problémem závislosti na pomoci je právě i její nespolehlivost: „Zrovna ted’ nám najednou z ničeho nic přestala dodávat pomoc jedna francouzská organizace, se kterou jsme dlouhodobě spolupracovaly. Nevíme proč. Prostě to nechápeme." Uprchlíci se tak domnívají, že nemají spolehlivě zajištěny základní životní potřeby. Zcela typicky a lapidárně nesnesitelnost podmínek v táboře Chánke shrnul šestašedesátiletý rolník Gúrí Ibráhím, původem z osady Til Banat: „Tohle není život. V táborech je život daleko horší než nám vláda slíbila, a než jsme tedy čekali." Jak mi v Dohúku řekl Khary B. Husien, hlavní zástupce Kurdské regionální vlády pro záležitosti jezídů: „Vydržet ve skromném provizoriu táborů lze týdny či měsíce. Nikoliv však roky."

Čtvrtým důvodem, proč jezídští muži nejsou schopni dostát tradiční roli výsadních živitelů svých rodin, je skutečnost, že k exodu jezídských uprchlíků na území iráckého Kurdistánu došlo ve stejné době, kdy zde vypukla komplexní ekonomická krize [viz Kamisher 2016]. Uprchlíci tak sice chtějí pracovat a živit své rodiny, trpí ale vysokou nezaměstnaností. Pracovních př́ležitostí není dostatek ani pro místní obyvatelstvo a uprchlické tábory navíc bývají situovány na periferii, mimo hlavní centra osídlení a ekonomické aktivity. Vedle nezaměstnanosti je dalším problémem bránícím v zabezpečení rodin inflace. Ceny potravin, bydlení i služeb totiž drasticky narůstají i z důvodu př́íchodu množství uprchlíků na území iráckého Kurdistánu.

\section{Přetížený kmenový kodex: Neschopnost uchránit „čistotu“ jezídských žen}

Jezídé ze Sindžáru jsou vychováváni tak, že čest a pověst rodiny je důležitější než život jednotlivce. Dívky unesené do sexuálního otroctví např́klad dávaly mnohdy přednost sebevraždě před zneužíváním [srov. Khalaf 2016]. V extrémním případě genocidy z rukou Islámského státu se důraz na tradiční pojetí cti projevoval tendencí dát přednost smrti před ponížením. Naif Jasim Mato, bratr starosty z obklíčené vesnice Kódžó, proto krátce před masakrem mužů a odvlečením žen a dětí do otroctví naléhal na velitele armádní letecké základny: „Prosil jsem ho, aby zaútočil na mou vesnici, mé syny, mé bratry, mé matky a sestry, protože to by pro nás bylo důstojnější. At̉ zaútočí na Daeš (Islámský stát) i na nás“ [Mato 2015: 59].

Nicméně prostředí uprchlických táborů vytváří dodatečné tlaky, které jezídské muže dále stresuje a generuje konflikty, jejichž motivem bývá snaha zachovat si tvář a dostát tradičním tribálním očekáváním nebo znovu získat ztracenou mužskou čest. Tábory jsou totiž překvapivě anonymní. Na malém prostoru sice žije mnoho lidí, nicméně jejich fyzickou blízkost provází nedůvěra a sociální distancovanost. Jak říká pologramotný stavební dělník ze severosindžárské střediskové obce Guhbal, Nawáf: „Po dvou letech se zde známe jen s lidmi ze sousedních stanů. Jsou to dobří lidé. Přátelíme se, i když jsme se předtím nikdy neviděli. Jinak se ale snažíme podporovat hlavně s pár dalšími krajany z našeho města, co sem také utekli."

Prvním problémem pro mužské osazenstvo táborů je skutečnost, že jsou zde příslušníci jednotlivých vesnic či kmenů nuceni žít v těsné blízkosti př́slušníkům jiných vesnic či kmenů, se kterými mají staré a nedořešené spory. To v minulosti, kdy jednotlivé jezídské kmeny a komunity žily na svých teritoriích a ve svých vesnicích, nebylo díky geografické 
distanci zásadním problémem. Pro lidi ze znesvářených rodin, vesnic či kmenů nebylo těžké se vzájemně vyhýbat a nepřijít do kontaktu. Konflikty proto propukaly jen zř́́dka. Po ruce navíc byly vždy kmenoví vůdci nebo náboženské autority, připravené konflikty moderovat a urovnat dř́ive, než by eskalovaly.

$\mathrm{V}$ přeplněných táborech namíchaných během uprchlictví z př́slušníků různých jezídských kmenů a vesnic ale nastává nová situace. Fyzická blízkost př́slušníků tradičně zneprátelených rodin, vesnic a kmenů je navíc umocněna tím, že jsou v situaci psychického traumatu, stresu a materiálního nedostatku nuceni soupeřit o př́stup $\mathrm{k}$ nedostatkovým zdrojům jako sprchy, potraviny, místa ve školách nebo pracovní př́ležitosti. To dále prohlubuje a posiluje tradiční segmentaci jezídské společnosti a vede $\mathrm{k}$ situacím, jež mohou rychle eskalovat $\mathrm{v}$ „kmenovou válku“ ve frontě na rýži nebo na toaletu. Ve vyhrocené situaci totiž ženy volají na pomoc své muže a muži své př́ibuzné, krajany z rodného města či př́slušníky stejného kmene. A pro ty je otázkou tradiční cti přispěchat na pomoc blízkým v nouzi. Koneckonců se jedná o reciprocitu, kdy se zase oni budou moci v nouzi spolehnout na druhé. Takový konflikt pak ale rychle eskaluje, když se na něj nabalují další lidé. A když zároveň chybí všemi uznávané autority, které by mohly takové konflikty moderovat k nenásilnému řešení. Nicméně řada mladších a vzdělanějších uprchlíků tvrdí, že tyto střety jdoucí vesměs po liniích tradičních pokrevních identit nepodporují. Například dvaadvacetiletý student angličtiny na univerzitě v Mosulu, Nádžim Chudžilí, se prý agresivních mužů vždy sugestivně ptá: „Pokud jsi opravdu takový chytrák a tak odvážný frajer, jak se tváríiš, proč vlastně sedíš tady v táboře? Proč raději nevyženeš Islámský stát z našich vesnic, abychom se mohli všichni vrátit domů?"

Vše je komplikováno kmenovým kodexem cti, v němž se prestiž rodiny a kmene odvijí od schopnosti mužů ochránit „čistotu“ ženských př́slušníkủ. Přitom právě v přeplněných táborech je to obtížnější než kdykoliv předtím. Na rozdíl od bezpečného a předvídatelného prostř̌edí tradiční komunity se ženy $\mathrm{v}$ přeplněných táborech dostávají do četných kontaktů s cizími muži z jiných rodin, vesnic a kmenů. Uchránit si soukromí a odstup je tak v táborech těžké. To zvyšuje tlak, který je na ženy kladen. Jak se v této věci typicky vyjádřila mladá studentka Nadžlá 'Abdulláh: „Je to stres. Jako svobodná dívka musím opatrně našlapovat, abych nešlápla vedle a neudělala chybu. Když udělá chybu muž, není to takový skandál. Čest rodiny a kmene se totiž primárně odvijí od př́íladného chování jejích ženských členů.“

Muži jsou přitom po genocidě z léta 2014 znejistělí a nervózní. Jejich kmenová čest, mužnost a hrdost totiž byla zásadně zpochybněna během znásilňování a únosů jezídských žen Islámským státem a arabskými sousedy. Své ženy a jejich čistotu tehdy nedokázali ochránit, nedostáli tak svým tradičním povinnostem a závazkům. Reagují proto na sebemenší náznak dalšího zpochybnění své cti přecitlivěle. A chtějí sami sobě i okolí dokázat, že své ženy již napříště ochránit dokáží. Mnohé konflikty mezi muži v uprchlických táborech tak lze interpretovat jako zástupné (nerealistické) konflikty, jež se neobracejí na skutečného viníka frustrací (Islámský stát), ale na náhradní cíle v podobě ostatních - podobně postižených - jezídských mužů. Muži tyto konflikty mohou vyhledávat, protože při nich mají př́ležitost nejen ventilovat frustraci, ale i demonstrovat skrze veřejně předváděnou agresivitu svou maskulinitu a obnovit tak svůj (sebe)obraz tradičního mužství. 


\section{Krize elit a zpochybnění patriarchálních autorit}

Posledním obecnějším důvodem, proč se drolí postavení mužů v jezídské společnosti je to, že došlo ke zpochybnění části patriarchálních jezídských autorit. Statusová krize jezídských mužů je součástí širší krize důvěry v mužské vůdce komunity. Tito vůdci rezignují na své tradiční funkce a neplní tradiční závazky, které vůči komunitě mají a jejichž plnění od nich komunity očekávají. Jak na adresu klíčových patriarchálních autorit poznamenal jezídský transkulturní psycholog zapojený do projektu terapeutické pomoci traumatizovaným jezídským dívkám a ženám, Ilhan Kizilhan: „Nejvyšší náboženská rada ani mír Tehsin Beg, sekulární vůdce jezídů, nebyli schopni ochránit svůj lid ani mu nabídnout jakoukoliv perspektivu. Staré instituce, jako je kastovní systém, mír, Bábá Šajch či Nejvyšší náboženská rada selhaly př̀i plnění svých funkcí tváří katastrofě“ [Omarkhali 2016: 154].

Výše uvedené hodnocení může být přiliš příkré, ve svém výzkumu jsem se setkal zejména s kritikou kmenových elit. Jezídské kmenové a stranické elity, vesměs kooptované do struktur Kurdské regionální vlády, údajně týdny a měsíce před útokem Islámského státu na Sindžár přesvědčovaly řadové jezídské obyvatelstvo, aby neutíkalo s odkazem na to, že je ochrání kurdská pešmerga. Plnily tak zadání Kurdské demokratické strany. Používaly její rétoriku a přitom využívaly autoritu, kterou v očích jezídů měly. Jezídé si nikdy nebyli jisti ujištováním Kurdské regionální vlády o neporazitelnosti statečné pešmergy. Ale uvěřili, když je o tom samém přesvědčovali vlastní vưdci. Patriarchální jezídské elity tak přispěly k tragédii, když své lidi odrazovaly od včasného odchodu. Avšak v momentě, kdy se pešmerga potají stáhla, své domovy v tajnosti opustili také kmenoví náčelníci a místní političtí předáci Kurdské demokratické strany. Jak mi řekl Šiwán: „Tihle lidé si dnes v pohodě žijí v pěkných čtvrtích v hlavním městě Arbílu nebo Dohúku. Zavčasu s rodinami utekli, protože měli jako jediní informaci o stažení pešmergy a o postupu Islámského státu. "Selhání jezídských elit přitom souvisí také s tím, že zbraně v té době neměl jen Islámský stát kurdská pešmerga. V táboře Chánke o tom za přikyvování ostatních rozhořčeně hovořila pětadvacetiletá negramotná Gulistán: „My nedáváme genocidu za vinu jen kurdské pešmerze, která nás přes všechny sliby nechala na holičkách. Nás přeci zradili i jezídští vůdci z kurdských politických stran. Také oni měli zbraně. Ale místo aby je použili pro ochranu vlastních lidí, tak raději utekli úplně stejně jako pešmerga. Pešmerga třeba kvůli nám nechtěla umírat. Ale naši vůdci tu povinnost měli. “

Patriarchální a tribální hierarchie, jejichž klíčovou komponentou je tradiční dělba genderových rolí, se dále drolí také z toho důvodu, že jezídské elity adekvátně nezareagovaly ani na následnou humanitární krizi. Jak mi řekla pětačtyřicetiletá Pírúz Ósmánová z uprchlického tábora Chánke: „Kmenoví náčelníci nám vůbec nepomáhají. Náš náčelník žije v klidu ve městě Zacho, kam utekl. Ale protože jsme z jiné politické strany než on, nikdy nás nenavštívil. Bud’ nás úplně ignoruje, nebo má dokonce tu drzost a čas od času nás žádá o podporu. Nás, kdo živoříme a nemáme již vůbec nic." Uprchlická krize navíc vedle odcizení elit a zhroucení jejich autority v očích běžných jezídů vedla také $\mathrm{k}$ vnitřnímu konfliktu mezi jezídskými elitami samotnými, což dále diskredituje [Schmidinger 2016]. Reakcí jezídů traumatizovaných uprchlictvím je pak revolta proti tradičním kulturním hierarchiím postaveným na tribalismu a patriarchalismu [After ISIS 2015: 68]. 


\section{Redefinice postavení jezídských žen: Krize i př́ležitost}

V reakci na ozbrojený konflikt, uprchlictví a následné zpochybnění tradičního statusu jezídských mužů dochází k pokusům redefinovat status jezídských žen i genderové vztahy jako takové. Ženy nově vstupují do oblastí tradičně vymezených mužům, když se výrazněji podílejí na materiálním zabezpečení rodiny nebo dokonce vstupují do ozbrojených složek. Ženy si dále osvojují nová očekávání a nové aspirace, poprvé v historii se tak např́iklad vymezují proti domácímu násilí a jsou dokonce otevřenější k tradičně tabuizovaným rozvodům. Konečně, v reakci na hromadné znásilňování jezídských žen prochází redefinicí také tradiční kodex ženské cti a čistoty. Dosud je přitom př́liš brzy odhadovat, zda se tyto tendence promění v dlouhodobý trend, nebo dojde k jejich modifikaci či zvrácení. Každopádně však tyto změny ukazují na možné dopady válečného konfliktu a uprchlictví na postavení žen v tradičních společnostech a na podobu genderových vztahů.

\section{Akceptování osvobozených sexuálních otrokyň}

Snad nejdiskutovanější změnou týkající se postavení žen, je tendence rodin a komunit přijímat i přes odpor konzervativců jezídské ženy, které se podařilo zachránit ze sexuálního otroctví. Tradiční postoj přitom požadoval exkomunikaci jezídů, kteří by snad porušili pravidla vnitřní (vztah mezi jezídy z různých kast) i vnější (vztah s nejezídy) endogamie. Masovost sexuálního zotročování jezídek z rukou islamistů však byla natolik bezprecedentní, že vyvolala podobně bezprecedentní reakci. Téměř každá rodina měla někoho, kdo byl postižen, sílily proto hlasy požadující nikoliv jejich exkomunikaci, ale reintegraci. Postižení jezídé uzpůsobují tradiční kulturu nové realitě, z obětí nechtějí dělat viníky. Bábá Šajch, hlavní náboženská autorita, proto vyhlásil, že znásilněné jezídky zůstávají i nadále součástí komunity se všemi právy, smějí se vdát a nikdo je nesmí diskriminovat. Bábá Šajch se dále s osvobozenými jezídkami a jejich rodinami setkává a účastní se jejich rituálního očištění v posvátném prameni ve svatyni v Láliši za přítomnosti dalších jezídů. Podobně Bábá Šajch a jezídský náboženský establishment upravuje další tradiční náboženské rituály pro nové potřeby, když např́iklad osobně podporuje účast traumatizovaných jezídek na terapeutických programech v Německu a před cestou je přijímá právě v Láliši [Omarkhali 2016].

Ne všichni jezídé však s tímto oficiálním a snad i mainstreamovým postojem souhlasí. Oběti sexuálního násilí z rukou islamistů totiž bývají podle řady svědectví okolím nadále stigmatizované [Khalaf 2016; Murad 2018]. Mnohé jejich problémy navíc zůstávají tabu. Mnohé ženy se ze zajetí např́klad vrátily těhotné. Ve vysoce konzervativní společnosti je však potrat nemyslitelný, jakkoliv k umělým přerušením těhotenství pokoutně a za vysokého rizika dochází. Jindy se znásilňované ženy za nejasných okolností zbavují novorozenců. A naprosto tabuizovanou novinkou zůstávají pohlavní nemoci, se kterými se dosud jezídské komunity nesetkaly [OSN 2016: 15].

\section{Ženy jako živitelky rodiny}

Uprchlictví vede k umenšení ekonomické závislosti jezídských žen na mužích, kteří přestávají být výhradními živiteli svých rodin. V reakci na uprchlickou krizi přišla do 
severního Iráku řada mezinárodních humanitárních organizací, jež jako své místní spolupracovníky a zaměstnance najímají rovným dílem muže i ženy. Řada ze západních i kurdských humanitárních a lidskoprávních organizací navíc cílí speciálně na ženské uprchlice, snaží se je vzdělávat a rekvalifikovat. Např́klad uprchlice v táboře Qádijá mi řekly, že se zde naučily spoustu nových věcí. Např́klad si pochvalovaly kurzy šití, kdy si osvojily nové techniky, rozšírily znalost látek a textilních materiálů, ale také zdokonalily dovednost obsluhovat šicí stroj. Na trhu práce jim ale prý může pomoci také to, že se teprve až při pobytu v táboře naučily různé dialekty kurdštiny a arabštiny, protože doma v Sindžáru s lidmi z jiných komunit téměř nepřišly do styku. Uprchlice konečně hovoří i o tom, že se v důsledku pobytu v táboře cítí jako ženy sebevědomější. Ve vesnicích v Sindžáru žily spíše izolovaně za zdmi svého domova a příliš se s ostatními jezídkami neznaly a nestýkaly. Dnes se naopak znají s mnoha ženami, navštěvují se, vyměňují si informace a sdílí svou životní zkušenost - prý i díky tomu, že jim táborová samospráva zřídila ženské centrum.

Samostatnou kapitolou jsou ženy, které kvưli konfliktu ovdověly. Jakkoliv traumat se ženy nikdy zcela nezbaví, genocida je nutí plně se emancipovat. Naprostá většina jezídek ze Sindžáru jsou přitom negramotné či minimálně vzdělané ženy, které byly ve velmi mladém věku provdané. V konzervativním a patriarchálním prostředí přitom byly zvyklé, že za ně rozhodoval a směrem navenek (sousedi, úřady) je zastupoval manžel, který je i živil. Mnozí manželé jsou však kvůli genocidě mrtví. A mnoho žen se již podruhé nevdá. Budou se proto muset naučit v životě orientovat a rozhodovat, přičemž na nich bude ležet i tíha péče o přeživší děti. Budou se proto muset naučit osobní a ekonomické nezávislosti, což bude v dosud tribálním a patriarchálním prostředí vyžadovat změnu postojů týkajících se genderových vztahů i ve zbytku komunity [OSN 2016].

\section{Ženy jako bojovnice}

Kromě toho, že v důsledku válečného konfliktu a uprchlictví jezídské ženy částečně přebírají tradičně mužskou funkci živitelů rodin, vstupují také do další ryze mužské domény: ozbrojených složek bojujících proti Islámskému státu. Jestliže se totiž tváří v tvář Islámskému státu nejprve zhroutila irácká armáda a poté jezídské vesnice navzdory slibům nebránila ani kurdská pešmerga, jedinou pomoc jezídům poskytli syrští Kurdové z marxistických Jednotek obrany lidu (YPG) napojení na tureckou Stranu pracujících Kurdistánu (PKK). Ty na pomoc jezídům obklíčeným na hoře Sindžár intervenovaly ze sousední Sýrie. Jak mi řekl Mathew Barber z jezídské organizace Yazda: „Zatímco uprchlíci humanitárním koridorem proudili do Sýrie a odtud pak složitě do iráckého Kurdistánu a provincie Dohúk, opačným směrem putovali bojovníci YPG a zbraně pro jezídské partyzány. Koridor sice neudrželi, ale v boji proti Islámskému státu pokračovali bok po boku v horách. Tím Kurdistánská regionální vláda Sindžár politicky ztratila. Odjakživa zde žilo konzervativní, zbožné a převážně venkovské obyvatelstvo, které marxismus nezajímal. Dnes ale z vděku se syrskými Kurdy dost možná sympatizuje více než s Kurdskou demokratickou stranou, které nemohou odpustit zradu.“

Změna postojů vyvolaná intervencí syrské marxistické guerilly se zřejmě týká i těch vưči genderovým rolím. Podle jezídských uprchlic z tábora Qádijá se jejich pohled na roli ženy radikálně proměnil, když v řadách YPG, jež jim přišla na pomoc, viděly bojovat mnoho žen. Dnes proto prý také jezídské dívky a ženy odcházejí bojovat s Islámským státem. 
A co je nejpodstatnější, dosud konzervativní komunita to podporuje a oslavuje. Jak mi řekla jedna z uprchlic: „Před rokem 2014 bych naprosto odmítala, aby žena vzala zbraň a šla bojovat. To by mi nepřišlo na mysl. Dnes takové ženy obdivuji. Staly jsme se sebevědomějšími a víme, že muže dokážeme ve většině činností zastoupit, protože si jsme rovni.“ Uprchlice mluvily o tom, že v různých jezídských jednotkách odhadem sloužilo asi pět se žen. Osobně prý znaly tři nebo čtyři takové ženy jen z tábora Qádijá.

\section{Změna postoje $k$ domácímu násilí a rozvodi̊m}

Podle kurdské sociální pracovnice Viján Ahmad Sadíqové z tábora Qádijá bylo domácí násilí mezi jezídy ze Sindžáru rozšířené vždy. Přitom zdůrazňuje, že domácí násilí nevyplývá z jezídského náboženství, ale spíše z mimořádně konzervativní a patriarchální kultury. Nejrozšířenější totiž bývalo právě mezi nejvíce konzervativními a od světa nejvíce izolovanými jezídy ze Sindžáru. Méně mezi jezídy z Šéchánu či Dohúku a vưbec nejméně mezi jezídy z provincie Arbíl či Slémání.

Přitom se podle některých hlasů domácí násilí v důsledku válečného konfliktu a uprchlictví zvýšilo. Muži i ženy jsou traumatizovaní a ve stresu, mají proto tendenci reagovat přecitlivěle a agresivně. Muži navíc cítí, že jejich maskulinita byla zpochybněna díky tomu, že nedokáží plnit tradiční role jako je zajištění obživy a bezpečí pro své rodiny a komunity. Pošramocené sebepojetí a hroutící se mužskou autoritu si pak mohou mimo jiné vynucovat i zvýšeným domácím násilím. Jiné hlasy naopak hovoří o tom, že prožité utrpení mnohé rodiny stmelilo a zlepšilo vztahy mezi rodinnými př́islušníky. Jak mi řekla jedna uprchlice z tábora Qádijá: „Díky tomu, co jsme zažili, jsme štastnější. Dř́ive mě můj syn v Sindžáru každý den bil. Ale díky útoku Islámského státu spousta jemu podobných lidí přišla o rodiče. Syn si mě dnes váží a již mě nebije.“

V uprchlických táborech se však jezídské ženy i muži poprvé ve svém životě dozvídají, že je domácí násilí neakceptovatelné. Různé nevládní organizace kladou důraz na práva žen a říkají jim, že je muž nesmí bít, že to není normální a že si to nemusejí nechat líbit. Podobně se snaží působit i na muže a také pro ně pořádají přednášky a workshopy. Nicméně pokud podle Viján Ahmad Sadíqové nepomůže intervence sociálních pracovníků, přichází na řadu právníci a eventualita rozvodu. Rozvod je nicméně chápán jako poslední řešení, pokud vše ostatní selhalo. Vedle sociálních pracovníků a právníků jsou v táborech navíc k dispozici př́klady rozvedených žen, které k eventualitě rozvodu inspirují ostatní konzervativně smýšlející jezídky. Odmítání domácího násilí a naopak akceptace rozvodů je také symptomem pádu autority tradičního kmenového práva, které stranilo mužům, na úkor práva občanského, které je založené na genderové rovnosti.

\section{Závěrečná diskuze: Krize mužství, vynucená emancipace žen a redefinice genderových vztahů}

Ozbrojený konflikt provázený následným uprchlictvím vede ke zpochybnění a možným transformacím tradičních genderových vztahů mezi konzervativními jezídy z iráckého Sindžáru. Změny ve společenském postavení jezídských žen jsou přitom do určité míry důsledkem změn v tradičním postavení jezídských mužů. Společenské role jezídských mužů a žen jsou totiž vzájemně komplementární, ženské role bez mužských nedávají 
smysl (a naopak), existuje mezi nimi poměrně striktní dělba práce. Proto změny v postavení mužů nutně vyvolávají změny v postavení žen (a naopak). Protože jsou tedy změny v postavení jezídských mužů důležité pro pochopení možných transformací týkajících se společenského postavení a situace žen, avšak zároveň na Západě přehlížené, tento text se je snažil zmapovat stejně podrobně, jako se následně snažil postihnout změny ve společenském postavení žen.

Jak vyplývá z otevřeného kódování provedených rozhovorů, muži přestávají být v důsledku ozbrojeného konfliktu a uprchlictví schopni plnit své tradiční funkce, sociální role a povinnosti: garantovat bezpečí svých rodin a komunit; zajistit svým rodinám a komunitám př́ijem, materiální zdroje a akceptovatelnou životní úroveň; ochránit rodinou a komunitní čest v souladu s kmenovým kodexem cti. Tváří v tvář ozbrojenému konfliktu a uprchlictví navíc došlo k selhání jezídských kmenových elit, jež je možno chápat jako strážce patriarchální a muži dominované společnosti. Jezídští muži jsou tedy v důsledku ozbrojeného konfliktu a uprchlictví traumatizovaní, frustrovaní a dezorientovaní. Jejich kmenovým kodexem cti a patriarchální kulturou formovaná maskulinita je zpochybněna, jejich sociální status ohrožen a jejich kladné sebepojetí oslabeno.

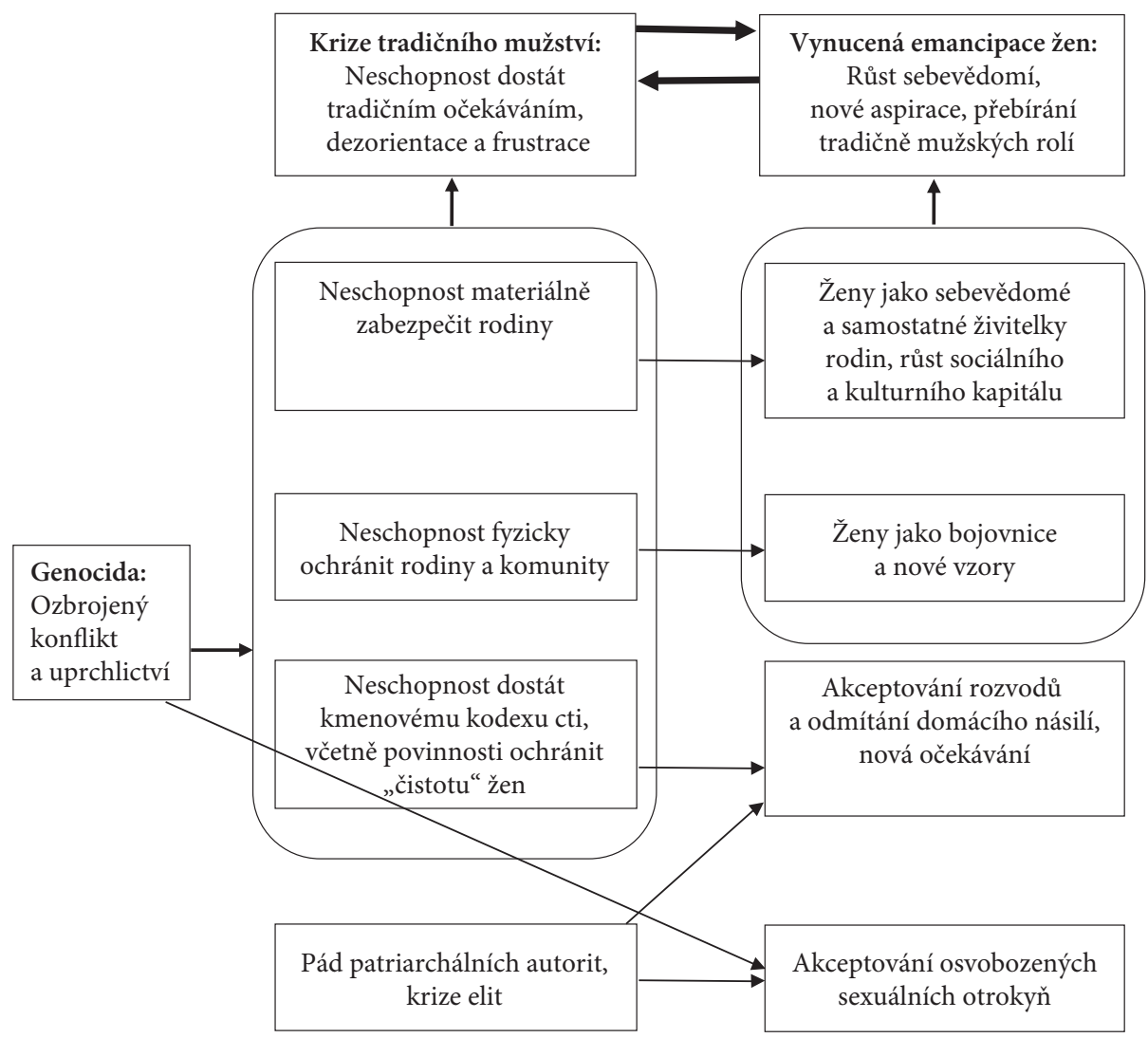

Obrázek 1: Redefinice genderových rolí a vztahů v důsledku jezídské genocidy 
V souvislosti s tím dochází k pokusům redefinovat sociální status jezídských žen, jak ukázalo provedené otevřené kódování. Ženy tak do určité míry doplňují či dokonce nahrazují (absentující či selhávající) muže v jejich tradičních funkcích a rolích: podílejí se ve zvýšené míre na materiálním zabezpečení rodin; přebírají (spolu)zodpovědnost za zajištění fyzického bezpečí rodin a komunit, když vstupují do ozbrojených složek. Ženy si též osvojují nové aspirace a nové pohledy na svět, přičemž zpochybňují zavedené zvyklosti vyplývající z patriarchální kultury či kmenového práva: požadují vzdělání nejen pro své syny, ale i dcery; přestávají akceptovat domácí násilí a naopak začínají akceptovat rozvody, jakkoliv jakožto nejkrajnější řešení rodinných rozporů. K patrně nejradikálnější, nejrychlejší a nejspektakulárnější transformaci došlo ve věci přijetí a pokusu o reintegrace jezídských dívek a žen, jež se podařilo zachránit ze sexuálního otroctví.

Na základě axiálního kódování se domníváme, že ozbrojený konflikt a následné uprchlictví měl př́mý dopad na postavení mužů a neprímý či zprostředkovaný dopad na postavení žen. Ozbrojený konflikt a uprchlictví s sebou totiž neslo důsledky (neschopnost materiálně zabezpečit rodiny, neschopnost fyzicky ochránit komunity, přetížení kmenového kodexu cti, zpochybnění patriarchálních autorit), jež nejprve vyvolaly krizi tradičního mužství.

To otevřelo prostor k tomu, že jezídské ženy mohly - nebo musely - převzít některé z tradičních rolí dosud vyhrazených mužům: jelikož muži nedokázali materiálně zabezpečit rodiny, začaly tuto funkci plnit i ženy; jelikož muži nedokázali fyzicky ochránit komunity, začalo být společensky akceptovatelné, že tuto funkci začaly plnit i ženy. Krize tradičního mužství kombinovaná s krizí patriarchálních autorit zpochybňující tradičně dominantní postavení mužů vůči ženám navíc napomohla redefinici domácího násilí (neakceptovatelné) a rozvodů (možné a akceptovatelné). Protějškem krize tradičního mužství je proto ozbrojeným konfliktem, uprchlictvím a následnou krizí tradičního mužství vynucená emancipace žen. Tato redefinice statusu jezídských žen ústící v jejich emancipaci pak ovšem sama vygenerovala další zpětné dopady na postavení jezídských mužů. Odpor žen vưči tradičním mužským privilegiím (domácí násilí) a zejména jejich nástup do dosud tradičně muži dominovaných sfér (materiální zajištění rodin, obrana komunit) dále posílil krizi tradičního mužství.

Selektivním kódováním jsme se zde tedy dopracovaly ke dvěma zastřešujícím a nejobecnějším procesům: krizi tradičního mužství přímo způsobeného ozbrojeným konfliktem a následným uprchlictvím, vynucenou emancipaci žen přímo způsobenou krizí tradičního mužství a nepřímo ozbrojeným konfliktem a uprchlictvím. Na nejobecnější úrovni tak vidíme, že krize tradičního mužství vyvolaná genocidou generuje emancipaci jezídských žen. A jejich emancipace zpětně podrývá tradiční postavení mužů a přispívá k jejich prohlubující se krizi, což může vytvářet dodatečný prostor či tlak na další ženskou emancipaci. Ozbrojený konflikt a následné uprchlictví vygenerovalo na ozbrojeném konfliktu a uprchlictví autonomní mechanismy, jež mohou působit a dokonce se skrze mechanismus zpětnovazebné spirály prohlubovat dlouho poté, co budou ozbrojený konflikt a uprchlictví, jež je původně uvedly v život, ukončeny.

Výše odhalené dílčí změny představují nově se vynořující tendence, které mohou být krátkodobé a zůstat omezené jen na malý segment jezídských uprchlíků. Nebo se mohou prosadit jako dlouhodobé trendy transformující celou jezídskou menšinu. Vycházejí z rozhovorů a z pozorování, jež byla v terénu provedena na jaře 2016. V době psaní tohoto textu je tedy ještě př́liš brzy odhadovat, jakým směrem se bude vývoje genderových vztahů 
mezi jezídy z iráckého Sindžáru vyvíjet. Pro vynášení spolehlivějších závěrů bude zapotřebí zopakování výzkumu s časovým odstupem a případně také doplnění kvalitativních výzkumných metod o metody kvantitativní. Jako nosné se jeví také komparace s jinými původně tradičními a patriarchálně organizovanými společnostmi, například Palestinců, v jejichž případě ozbrojený konflikt a následné uprchlictví urychlil procesy souhrnně označované jako modernizační: individualizaci, urbanizaci, růst vzdělání, expozici vůči mediálním obsahům, vytváření národní identity.

\section{Literatura}

Acikyildiz, Birgül [2010]. The Yezidis. The history of a community, culture and Religion. London: I. B. Tauris. After ISIS. Perspectives of displaced communities from Ninewa on return to Iraq's disputed Territory [2015]. Utrecht: Pax.

Ajaj, Hyad [2015]. Slavery Back into Practice by ISIS: Yazidy Women and Girls as a Sample. Lalish 41: 3-6.

Buffo, Veronica - Allison, Christine [2016]. The gendering of victimhood: Western media, and the Sinjar genocide. Kurdish Studies 4 (2): 176-196.

Castelier, Sebastian - Daycar, Laurène [2018]. Back from hell: The Yazidi women who survived the Islamic State [2018]. Middle East Eye, 3. 8. 2018. Dostupné z: www.middleeasteye.net.

Cumming-Bruce, Nick [2016]. ISIS Committed Genocide Against Yazidis in Syria and Iraq, U. N. Panel Says. The New York Times, 17. 6. 2016. Dostupné z: http://www.nytimes.com.

Domle, Khidher [2013]. Yazidis: A Deep-Rooted Community in an Unstable Present. In. Saloum, Sa'ad (ed.). Minorities in Iraq. Memory, Identity and Challenges. Bagdád - Bejrút, s. 66-78.

Domle, Khidher [2014]. The Black Death. Tragedies of Ezidy Women in the Grip of ISIS (Místo vydání a vydavatel neuvedeno).

Dulz, Irene [2016]. The displacement of the Yezidis after the rise of ISIS in Northern Iraq. Kurdish Studies 4 (2): 131-147.

Ekin, Annette [2018]. Jan Kizilhan: ISIL rape victims need culture-sensitive therapy. Al Jazeera English, 11. 6. 2018. Dostupné z: www.aljazeera.com.

Fallon, Katy [2018]. Yazidis seek church asylum as Europe's empathy for refugees wanes[2018]. Al Jazeera English, 29. 8. 2018. Dostupné z: www.aljazeera.com.

Foster, Johanna - Minwalla, Sherizaan [2018]. Voices of Yazidi women: Perceptions of journalistic practices in the reporting of ISIS sexual violence. Women's Studies International Forum 67 (2018): 53-64.

Growing numbers of Yezidis emigrating [2017]. Rudaw, 30. 3. 2017. Dostupné z: http://www.rudaw.net /english/kurdistan/290320175.

Hagedorn, Elizabeth [2018]. Unable to grieve. Iraq's Yazidis trapped in limbo as mass graves left untouched. Middle East Eye, 2. 10. 2018. Dostupné z: www.middleeasteye.net.

Hendl, Jan [2005]. Základy kvalitativního výzkumu. Praha: Portál.

Jírů, Lucie [2015]. Role kmenů v Iráku: Od Osmanské řiše po Islámský stát. In. Černý, Karel - Tureček, Břetislav (ed.). Význam kmenové společnosti v 21. století. Praha: Nakladatelství Lidové noviny, s. 47-87.

Kamisher, Eliyahu [2016]. How the KRG Quasi-State Built and Independent Oil Industry. Middle East Economy 6 (1). Dostupné z: http://dayan.org/content/iqtisadi-how-krg-quasi-state-built-independent -oil-industry.

Khalaf, Farida [2016]. The Girl Who Beat ISIS. My Story (spolu s Andrea C. Hoffmann). London: Square Peg.

Khanki, Kovan [2015]. Crimes and Sexual Abuse Committed Against Ezidies. Lalish 40: 16-24.

Kikoler, Naomi [2015]. Our Generation is Gone. The Islamic State's Targeting of Iraqi Minorities in Ninewa. Washington, DC: United States Holocaust Memorial Museum.

Knights, Michael [2017]. Turkey’s Waiting Game in Sinjar. Turkeyskope 1 (8). Dostupné z: http://www .washingtoninstitute.org/policy-analysis/view/turkeys-waiting-game-in-sinjar.

Kubálek, Petr [2007]. Problémy studia dějin jezídismu [online]. Dostupné z: http://kurdove.ecn.cz. 
Kubálek, Petr [2015]. End of Islam, End of Time. An Eschatological Reading of Yezidism. Archiv Orientální 83 (3): 569-598.

Kubálek, Petr [2016]. Jezídi. In. Gebelt, Jiří (ed.). Ve stínu islámu. Praha: Vyšehrad, s. 120-150.

Kudrnáč, Aleš [2011]. Stát ve stínu? Př́padová studie iráckého Kurdistánu 1970-2003. Bakalářská práce. Olomouc: Univerzita Palackého v Olomouci.

Maisel, Sebastian [2008]. Social change amidst terror and discrimination: Yezidis in the New Iraq. The Middle East Institute Policy Brief 18, srpen 2008.

Mato, Naif Jasim [2016]. The Massacre of Koco: Testimony. Wiener Jahrbuch für Kursische Studien 4: 57-59.

Murádová, Nádija [2018]. Poslední dívka. Svědectví ženy, která přežila genocidu jezídů. Praha: Ikar.

Omarkhali, Khanna [2016]. Transformations in the Yezidi tradition after the ISIS attacks: An interview with Ilhan Kizilhan. Kurdish Studies 4 (2): 148-154.

OSN [2015]. Tragedy of Even Greater Proportion in Iraq should be Urgently Prevented. Lalish, zima 2015: $10-12$.

OSN, Human Rights Council [2016]. „They came to destroy“: ISIS crimes against the Yazidis. New York: United Nations.

Salloum, Sa’ad [2013]. Minorities in Iraq. Memory, Identity and Challenges. Bagdád - Bejrút.

Schmidinger, Thomas [2016]. Singal nach dem Genocid: Die Politische und militarische Entwicklung in der Region seit 2014. Wiener Jahrbuch für Kursische Studien 4: 33-55.

Spät, Eszter [2016]. Hola hola Tawusi Melek, hola hola sehidet Singale: Persecution and the development of Yezidi ritual life. Kurdish Studies 4 (2): 155-175.

Strauss, Anselm - Corbinová, Juliet [1999]. Základy kvalitativního výzkumu. Postupy a techniky metody zakotvené teorie. Brno: Sdružení podané ruce.

The Revival of Slavery Before the Hour [2014]. Dabiq 4: 14-16.

UN Habitat [2015]. Emerging Land Tenure Issues Among Displaced Yazidis from Sinjar, Iraq. How chances of return may be further undermined by a discrimination policy dating back 40 years. New York: United Nations.

Yazda [2016]. Mass Graves of Yazidis Miller by the Islamic State Organization or Local Affiliates On or After August 3, 2014. Dohúk - Zeriland.

Karel Černý pưsobí jako sociolog na Fakultě humanitních studií Univerzity Karlovy. Zabývá se historickou sociologií, sociologií modernizace a konfliktu. Tematicky se orientuje na současný Blizký východ v historicko-sociologické a komparativní perspektivě. Kromě toho se zabývá také migrací a integrací přistěhovalců z převážně muslimských zemí do západních společností. Získal Cenu Jaroslava Krejčího (2012), vedl grant GAČR rozkrývající príčiny arabských revolucí (2013-2015) a v rámci Fulbrightova stipendia pobýval na Kalifornské univerzitě v Santa Barbaře (2012-2013), kde studoval americké muslimy. Vydal knihu Velká blízkovýchodní nestabilita (2017). Na základě terénního výzkumu uprchlictví v severním Iráku také napsal monografii Jezídové - komunita na útěku (2016). 